ISSN : $2302-1590$

E-ISSN: $2460-190 \mathrm{X}$

ECONOMICA

Journal of Economic and Economic Education Vol.4 No.1 (19-29)

\title{
ANALISIS FAKTOR-FAKTOR YANG MEMPENGARUHI PRESTASI BELAJAR MAHASISWA FAKULTAS EKONOMI UNIVERSITAS NEGERI PADANG
}

\author{
Vella Anggresta \\ Dosen Program Studi Pendidikan Ekonomi STKIP- PGRI Sumbar \\ Jl. Gunung Pangilun No.1, Padang Sumatera Barat \\ Email : vellaanggresta@yahoo.com
}

\begin{abstract}
Submitted: 2015.12.02 Reviewed: 2016.06.20 Accepted: 2016.06.20
http://dx.doi.org/10.22202/economica.2015.v4.i1.325
\end{abstract}

\begin{abstract}
This study aimed to analyze and see the influence of factors influencing students' achievement of Economical Faculty of Padang State University. This study was explorative study. The population was all of students majoring in S1 Economical Faculty of Padang State University; the total was 1546 students. In taking the sample, it was used the proportional random sampling with the total sample was 318 students. The data were analyzed by using descriptive analysis, factorial analysis, and regression analysis and the hypothesis was analyzed by using T-test. The result showed that (1) there were eight factors influence the students' achievement such as (a) teaching quality factors included lecturers' creativity, lecturers' understanding, facilities, learning references, and learning atmosphere in campus; (b) independency factors included competitive atmosphere, taking initiative, teamwork, and study preparation; (c) internal condition factors included living atmosphere, family relationship, and parents' attention; (d) ethic factors included learning motivation, learning effort, and ability to solve the problems; (e) concentration variables included physic condition, tiredness, and learning variables; (f) eating habit and achievement factors include eating and achievement to be succeed; (g) supplement factors included learning atmosphere, financial condition and participation in learning; (h) caring factors include how the parents treated the children. (2) the regression showed that the eating habit, achievement to be succeed and caring variables were not significantly influence toward students achievement
\end{abstract}

\section{Abstrak}

Penelitian ini bertujuan untuk menganalisis dan melihat pengaruh faktor-faktor yang mempengaruhi prestasi belajar mahasiswa Fakultas Ekonomi Universitas Negeri Padang. Jenis penelitian ini adalah eksploratif. Populasi penelitian ini adalah seluruh mahasiswa program studi S1 Fakultas Ekonomi Universitas Negeri Padang yang berjumlah 1546 orang. Teknik penarikan sampel dengan proportional random sampling dengan jumlah sampel sebanyak 318 orang. Teknik analisis data dengan menggunakan analisis deskriptif dan analisis faktor dan analisis regresi berganda. Hasil penelitian menunjukkan bahwa: (1) terdapat delapan faktor yang mempengaruhi prestasi belajar mahasiswa FE UNP diantaranya (a) faktor kualitas pengajaran, yang terdiri atas kreativitas dosen, pemahaman dosen, ketersediaan sarana dan prasarana, referensi belajar dan suasana belajar di kampus, (b) faktor kemandirian, faktor yang terdiri atas hasrat bersaing, mengambil inisitif, kerjasama dan persiapan belajar (c) faktor kondisi internal, yang terdiri atas suasana tempat tinggal, hubungan keluarga dan perhatian orang tua, (d) faktor etos kerja, faktor-faktor yang terdapat pada variabel ini yaitu kemauan belajar, kesungguhan diri dan kemampuan menyelesaikan masalah, (e) faktor konsentrasi, yang terdiri atas kondisi fisik, kelelahan dan perhatian belajar (f) faktor pola makan dan keinginan berhasil, (g) faktor penunjang yang terdiri atas kondisi belajar, ekonomi keluarga dan aktif dalam belajar (h) faktor pola asuh yang terdiri atas cara didikan orang tua. (2) uji lanjutan analisis regresi menyatakan bahwa pola makan dan keinginan berhasil, serta pola asuh tidak berpengaruh signifikan terhadap prestasi belajar mahasiswa.

Keywords: Faktor Internal, Faktor Ekternal dan Prestasi Belajar

(C2015 Prodi Pendidikan Ekonomi STKIP PGRI, Padang 


\section{PENDAHULUAN}

Memasuki abad ke-21 sekarang ini, Pendidikan Indonesia dihadapkan dengan sejumlah tantangan dan peluang, yang tentunya berbeda dengan jaman-jaman sebelumnya. Pendidikan yang sebelumnya berpusat pada guru bergeser menjadi berpusat pada siswa. Dari satu arah menjadi interaktif. Dari penggunaan alat tunggal menjadi multimedia. Guna mengantisipasi dan menyesuaikan diri dengan berbagai tuntutan dan dinamika perubahan yang sedang dan akan terus berlangsung di Abad ke-21 ini, lembaga pendidikan dituntut meningkatkan mutu pendidikan agar menghasilkan lulusan yang memiliki daya saing dan siap menjawab tantangan globalisasi.

Salah satu cara untuk mengukur kualitas lulusan pendidikan adalah dengan melihat prestasinya yang tergambar melalui Indeks Prestasi Komulatif (IPK). IPK merupakan tolak ukur penguasaan akademik mahasiswa. Semakin baik penguasaan akademik mahasiswa maka prestasi yang diperolehpun akan baik pula.

Ada beberapa faktor menurut Muhibiin Syah (2010:65) yang mempengaruhi IPK mahasiswa, yaitu faktor internal, faktor eksternal, dan faktor pendekatan belajar. Faktor internal terdiri dari aspek fisiologis (status gizi, kesehatan, dan kebiasaan sarapan pagi) dan aspek psikologis (intelegensi, sikap, bakat, minat, dan motivasi). Faktor eksternal terdiri dari lingkungan sosial (pendidikan ayah, pendidikan ibu, keadaan ekonomi orang tua, guru, teman-teman, dan masyarakat) dan lingkungan non sosial (lingkungan sekolah dan lingkungan tempat tinggal). Faktor pendekatan belajar yaitu jenis upaya belajar siswa yang meliputi strategi dan metode yang digunakan siswa untuk melakukan kegiatan pembelajaran materi-materi pembelajaran.

Di Indonesia secara umum, terdapat dua jenis perguruan tinggi yaitu yang dikelola oleh pihak swasta atau perguruan tinggi swasta dan perguruan tinggi negeri. Pada saat ini perguruan tinggi negeri masih menjadi favorit, namun di masa yang akan datang seperti yang terjadi di luar negeri, perguruan tinggi swasta lebih diminati karena mampu menghasilkan lulusan yang lebih berkualitas dan berdaya saing.

Fakultas Ekonomi UNP merupakan salah satu fakultas yang banyak diminati oleh saat ujian seleksi masuk Perguruan Tinggi. Jumlahnya mengalami peningkatan dari tahun ke tahun, sehingga persaingan masuk pun semakin kompetitif. Dengan persaingan yang ketat tersebut dapat diasumsikan bahwa input mahasiswa yang lulus memiliki kualitas yang baik. Namun, kenyataannya di lapangan ditemui bahwa input yang baik dari seleksi penerimaaan mahasiswa yang ketat tersebut tidak selalu menjamin mahasiswa akan memperoleh IPK yang baik. IPK yang diperoleh mahasiswa masih mengalami fluktuasi bahkan masih ada yang belum memenuhi standar dunia kerja. Sebesar $35,06 \%$ mahasiswa Fakultas Ekonomi UNP memiliki IPK kurang dari 2,75.

Berdasarkan wawancara yang penulis lakukan terhadap mahasiswa Fakultas Ekonomi UNP, diperoleh informasi bahwa faktor yang menjadi penyebab buruknya prestasi belajar adalah ketidakmampuan mahasiswa mengatur waktu dalam belajar, kebiasaan begadang yang mengakibatkan tubuh mudah lelah. Penyebab lain adalah lingkungan pertemanan yang tidak saling mendukung dalam perkuliahan. Sebagian mahasiswa mengatakan sulitnya mengakses referensi buku perkuliahan dan kurangnya minat terhadap mata kuliah tertentu merupakan faktor yang paling berpengaruh terhadap prestasinya.

Ada banyak faktor yang mempengaruhi prestasi belajar menurut oleh para ahli. Suryabrata (2009:233) mengungkapkan bahwa prestasi belajar dapat dipengaruhi oleh: faktor non-sosial yang meliputi udara, suhu, cuaca, waktu, dan lokasi; faktor sosial yang meliputi pengaruh mahasiswa di sekitar siswa; faktor fisiologis atau kondisi fisik; dan faktor psikologis atau kondisi kejiwaan. 
Sementara Ahmadi (2010:63-68) berpendapat bahwa presatsi belajar dipengaruhi oleh kemampuan yang sifatnya genetis, kondisi fisik, kondisi psikis, kemauan belajar, sikap terhadap pengajar, ketersediaannya pembimbing, serta adanya evaluasi atau ulangan.

Berdasarkan permasalahan tersebut, penulis menelusuri faktor-faktor dominan yang mempengaruhi prestasi belajar mahasiswa Fakultas Ekonomi UNP dan menemukan bagaimana faktor tersebut dapat mempengaruhi prestasi belajar mereka. Oleh karena itu, penelitian ini diberi judul "Analisis Faktor-faktor yang Menpengaruhi Prestasi Belajar Mahasiswa Fakultas Ekonomi Universitas Negeri Padang." Penelitian ini bertujuan untuk mengungkapkan faktor-faktor dominan yang mempengaruhi prestasi belajar mahasiswa Fakultas Ekonomi Universitas Negeri Padang

\section{METODE PENELITIAN}

Penelitian ini adalah penelitian survei dimana penelitian dilakukan dengan mengambil sampel dari satu populasi dan menggunakan kuesioner sebagai alat pengumpul data. Penelitian ini berjenis eksploratif yang berupaya memberikan penjelasan atas suatu permasalahan, bertujuan untuk mencari data sebanyak-banyaknya tentang faktor-faktor yang mempengaruhi mahasiswa dalam memperoleh prestasi belajar pada mahasiswa Fakultas Ekonomi Universitas Negeri Padang.

Penelitian ini dilakukan di Fakultas Ekonomi Universitas Negeri Padang pada bulan April 2014. Populasi dari penelitian ini adalah seluruh mahasiswa jurusan akutansi Fakultas Ekonomi Universitas Negeri Padang tahun masuk 2010, 2011 dan 2012. Adapun jumlah populasi dalam penelitian ini sebanyak 1546 orang siswa.

\section{Tabel 1. Rincian jumlah populasi dalam penelitian}

\begin{tabular}{cccccc}
\hline \multirow{2}{*}{ NO } & \multirow{2}{*}{ Jurusan } & \multicolumn{2}{c}{ Tahun Masuk } & \multicolumn{2}{c}{ Jumlah } \\
\cline { 3 - 6 } & & $\mathbf{2 0 1 0}$ & $\mathbf{2 0 1 1}$ & $\mathbf{2 0 1 2}$ & \\
\hline 1 & Akuntansi & 168 & 130 & 109 & 407 \\
2 & Manajemen & 172 & 145 & 121 & 438 \\
3 & Pendidikan Ekonomi & 136 & 105 & 112 & 353 \\
4 & Ekonomi Pembangunan & 111 & 108 & 105 & 324 \\
& Jumlah & & & & \multicolumn{2}{c}{1546} \\
\end{tabular}

Sumber: Tata Usaha FE UNP, 2014

Melihat jumlah populasi yang cukup besar, maka pengambilan sampel dilakukan dengan teknik proportional random sampling menurut Ridwan (2006:65) Sehingga kemudian diperoleh 318 orang mahasiswa. 
Tabel 2. Pengambilan sample

\begin{tabular}{ccc}
\hline \multirow{2}{*}{ Program Studi } & Tahun Masuk & Pengambilan Sampel \\
& & \\
\hline \multirow{2}{*}{ Akuntansi } & 2010 & 35 orang \\
& 2011 & 28 orang \\
Manajemen & 2012 & 23 orang \\
& 2010 & 36 orang \\
Pendidikan Ekonomi & 2011 & 30 orang \\
Ekonomi & 2012 & 25 orang \\
pembangunan & 2010 & 22 orang \\
& 2012 & 23 orang \\
& 2010 & 23 orang \\
& 2011 & 23 orang \\
\hline
\end{tabular}

Sumber: Pengolahan Data Primer, 2014

Sesuai dengan jenis data yang diperlukan terdapat 2 jenis instrumen pengumpulan data yang digunakan, yaitu berbentuk format dokumenter dan kuisioner. Format dokumenter digunakan untuk mendapatkan mutu hasil belajar mahasiswa yaitu berupa nilai akhir. Sedangkan format kuisioner/angket digunakan untuk mengumpulkan data tentang faktor yang menjadi keberhasilan bagi mahasiswa dalam belajar. Penyusunan instrumen yang berbentuk kuisioner dilakukan melalui beberapa tahap, yaitu tahap penentuan kisikisi indikator; tahap penyusunan butir-butir instrumen; tahap uji coba instrumen penelitian.

Selanjutnya teknik analisis data yang dilakukan adalah analisis deskriptif. Teknik analisis deskriptif yang digunakan untuk menggambarkan keadaan gejala sosial dari lokasi penelitian, objek penelitian serta distribusi item-item dari masing-masing faktor yang disajikan dalam tabel, kemudian dilakukan pembahasan secara deskriptif dalam angka dan persentase.

Selanjutnya, penulis melakukan analisis faktor guna untuk mengenali dimensi pokok atau keteraturan dari sebuah fenomena. Tujuan umum dari analisis faktor adalah untuk meringkas kandungan informasi variabel dalam jumlah yang besar menjadi sejumlah faktor yang lebih kecil.

Berdasarkan faktor dasar yang telah diperoleh dari analisis faktor, maka faktor baru akan dilanjutkan dengan analisis regresi berganda untuk mengungkapkan dan melihat secara riil bagaimana pengaruhnya terhadap prestasi belajar mahasiswa FE UNP.

\section{PEMBAHASAN}

Hasil analisis faktor dari penelitian ini sebagai berikut:

\section{Memilih Variabel Matriks Korelasi}

Memilih variabel matriks dilakukan dengan menggunakan analisis KMO and Bartlett's test untuk menentukan apakah semua faktor dapat dianalisis lebih lanjut dengan nilai $K M O$ yang diperoleh besar dari 0,05 . Selanjutnya nilai MSA yang dapat dilihat pada nilai Anti Image Matriks dimana faktor dengan nilai MSA $<0,5$ harus dihilangkan untuk analisis lebih lanjut. Dalam penelitian ini faktor tepat waktu dihilangkan 
untuk analisis lebih lanjut karena memperoleh nilai 0,494 .

\section{Communalities}

Proses analisis faktor tahap kedua yaitu untuk mengetahui apakah variabel yang layak diuji tersebut bisa direduksi menjadi satu atau lebih faktor. Pada SPSS hal ini mengacu pada tabel Communalities. Communalities adalah jumlah varian dari suatu variabel mula-mula yang bias dijelaskan oleh faktor yana ada. Semakin besar communalities maka semakin erat hubungannya dengan faktor yang terbentuk.

\section{Menerangkan Nilai Variance}

Merupakan sebuah analisis yang digunakan untuk melihat berapa jumlah faktor optimal dalam menjelaskan variance 29 indikator yang akan membentuk faktor. Penentuan jumalah faktor yang layak dapat dilihat dari nilai eigenvalue lebih dari satu. Persentase varian dan kumulatif masingmasing faktor yang terbentuk dapat dilihat pada tabel 3 dibawah ini:

Tabel 3. Total Varince Explained

\begin{tabular}{cccc}
\hline \multirow{2}{*}{ Faktor } & \multicolumn{3}{c}{ Initial Eigenvalues } \\
\cline { 2 - 4 } & Eigenvalues & \% Variance & Cumulative \% \\
\hline 1 & 7.855 & 28.053 & 28.053 \\
2 & 2.635 & 9.409 & 37.463 \\
3 & 1.822 & 6.507 & 43.969 \\
4 & 1.732 & 6.185 & 50.154 \\
5 & 1.609 & 5.745 & 55.900 \\
6 & 1.331 & 4.755 & 60.655 \\
7 & 1.258 & 4.494 & 65.149 \\
8 & 1.159 & 4.141 & 69.290 \\
\hline
\end{tabular}

Sumber: Hasil Olahan Data SPSS, 2014

\section{Faktor sebelum Rotasi}

Matriks faktor distribusi indikator sebelum rotasi masih dijumpai sebuah bentuk struktur data yang belum sederhana. Hal ini karena tidak seluruh faktor memiliki koefisien loading factor yang cukup mewakili, sehingga ada faktor yang diwakili oleh banyak indikator akan tetapi adapula faktor lain yang tidak diwakili oleh satupun indikator. Berikut dapat dilihat pada tabel 4 di bawah ini:

\section{Tabel 4: Komponen Matriks}

\begin{tabular}{lccc}
\hline No & Sub Indikator & Loading Factor & Identifikasi Faktor \\
\hline 1 & Pemahaman Dosen & 0,713 & \\
2 & Mengambil Inisitif & 0,712 & \\
3 & Memecahkan masalah & 0,709 & Faktor 1 \\
4 & Semangat belajar & 0,695 & \\
5 & Suasana kampus & 0,690 & \\
7 & Kreativitas & 0.689 & \\
\hline
\end{tabular}




\begin{tabular}{cccl}
\hline 8 & Kerjasama & 0,636 & \\
9 & Referensi Belajar & 0,572 & \\
10 & Keinginan Berhasil & 0,560 & \\
11 & Persiapan Belajar & 0,537 & \\
12 & Sarana dan prasarana & 0,526 & \\
13 & Suasana tempat tinggal & 0,647 & Faktor 2 \\
14 & Hub keluarga & 0,625 & \\
15 & Perhatian orang tua & 0,606 & Faktor 3 \\
16 & Kesungguhan diri & 0,551 & Faktor 5 \\
17 & Pola makan & 0,567 & \\
18 & Ekonomi Keluarga & 0,542 & Faktor 7 \\
19 & Kondisi belajar & 0,495 & Faktor 8 \\
20 & Didikan orang tua & 0,565 & \\
\hline
\end{tabular}

Sumber: Hasil Olahan Data SPSS 2014

\section{Rotasi Faktor}

Setelah dilakukan rotasi faktor diketahui bahwa terdapat faktor 4 faktor yang mempunyai faktor loading kurang dari 0,5 sehingga harus dikeluarkan dari model yaitu faktor strategi belajar dengan nilai 0,468 , faktor semangat belajar dengan nilai loading
0,479 , faktor tekun dalam mengerjakan tugas 0,472 dan faktor teman sebaya sebesar 0,342 Hal ini dapat dilihat pada tabel Rotated Component Matrik yang dapat ditunjukkan pada tabel 5 sebagai berikut:

\section{Tabel 5: Komponen Matriks Setelah Rotasi}

\begin{tabular}{lcc}
\hline \multicolumn{1}{c}{ Sub Indikator } & Loading Factor & Identifikasi Faktor \\
\hline 1. Kreativitas & 0.847 & Faktor 1 \\
2. Pemahaman & 0.705 & \\
3. Sarana dan Prasarana & 0.643 & Faktor 2 \\
4. Referensi & 0.555 & \\
5. Suasana Kampus & 0.545 & Faktor 3 \\
1. Hasrat Bersaing & 0.749 & \\
2. Mengambil Inisiatif & 0.702 & 0.638 \\
3. Kerjasama & 0.571 & 0.845 \\
4. Persiapan Belajar & 0.801 & Faktor 4 \\
1. Suasana Tempat Tinggal & 0.701 & \\
2. Hubungan Keluarga & 0.800 & \\
3. Perhatian Orang Tua & 0.613 & \\
1. Kemauan Belajar & 0.524 & \\
2. Kesungguhan Diri & & \\
3. Memecahkan masalah & & \\
\hline
\end{tabular}


1. Kondisi Fisik

2. Kelelahan dalam Belajar

3. Perhatian dalam Belajar

1. Pola Makan

2. Keinginan Berhasil

1. Kondisi Belajar

2. Ekonomi Keluarga

3. Aktif dalam Belajar

1. Didikan Orang Tua
0.778

0.681

Faktor 5

0.611

0.800

0.597

0.678

0.612

0.576

0.800
Faktor 6

Faktor 7

Faktor 8

\section{Sumber: Hasil Olahan Data SPSS 2014}

Berdasarkan analisis faktor yang telah dilakukan terbentuk 8 faktor yaitu:

Faktor 1 diberi nama Kualitas Pengajaran yang terdiri dari kreativitas dosen, pemahaman materi dosen, kelengkapan sarana prasarana, referansi belajar dan suasana kampus. Faktor ini dapat menjelaskan keberagamaan varian sebesar varian sebesar 28.053\%. Apabila dilihat dari faktor loadingnya indikator-indikator dalam faktor ini memiliki range loading faktor dari 0,545 sampai dengan 0,847 ini berarti korelasi antara indikator dengan faktor berkisar antara $54,5 \%$ hingga $84,7 \%$. Faktor loading kreativitas dosen dalam mengajar yang paling menentukan keberhasilan mahasiswa FE UNP dalam memperoleh prestasi yang baik dengan nilai sebesar 0,874 , sedangkan nilai terendah pada faktor suasana belajar di kampus sebesar 0,545. Hal ini juga sesuai dengan hasil distribusi frekuensi yang dilakukan dengan tingkat ketercapaian responden (TCR) pada kreativitas dosen sebesar 80,53\%.

Menurut Mariani (2009:6) faktor kreativitas dosen, pemahaman dosen, ketersediaan sarana dan prasarana, referensi belajar dan suasana belajar di kampus termasuk dalam kelompok faktor yang meningkatkan kualitas pengajaran. Kualitas pengajaran akan didukung oleh keterkaitan sistematik dan sinergi dosen, mahasiswa, materi, sarana dan prasarana belajar, rujukan sumber bacaaan terbaru yang menambah wawasan mahasiswa dan iklim yang kondusif dalam belajar
Faktor 2 diberi nama kemandirian belajar yang mempunyai nilai eigenvalues sebesar 2.635. Indikator yang terdapat pada faktor ini yaitu hasrat untuk bersaing, mengambil inisitif dalam belajar, kerjasama dan persiapan belajar. Faktor ini dapat menjelaskan keberagamaan varian sebesar varian sebesar 9,409\%. Apabila dilihat dari faktor loadingnya indikator-indikator dalam faktor ini memiliki range loading faktor dari 0,571 sampai dengan 0,749 ini berarti korelasi antara indikator dengan faktor berkisar antara $57,1 \%$ hingga $74,9 \%$. Faktor loading hasrat untuk bersaing dalam belajar mempengaruhi keberhasilan mahasiswa FE UNP dalam memperoleh prestasi belajar yang baik dengan nilai sebesar 0,749 , sedangkan nilai terendah pada persiapan belajar yang dilakukan sebesar 0,571. Hal ini juga sesuai dengan hasil distribusi frekuensi yang dilakukan dengan tingkat ketercapaian responden (TCR) hasrat bersaing sebesar $83.84 \%$

Hasil ini didukung oleh pendapat Sardiman (2008:45) faktor keinginan bersaing, mengambil inisitif dan persiapan belajar termasuk ke dalam faktor kemandirian belajar sedangkan sedangkan kerjasama mengelompok pada interaksi social . Seseorang yang memiliki kemandirian dalam belajar akan didasari atas kecendrungan untuk maju, penuh inisitif dan penuh perencanaan dalam belajar untuk mewujudkan harapan yang ingin dicapai

Faktor $\mathbf{3}$ diberi nama lingkungan keluarga dalam belajar dengan nilai eigen 
values sebesar 1.822. indikator yang terdapat pada faktor ini yaitu suasana tempat tinggal, hubungan dengan keluarga dan perhatian orang tua. Apabila dilihat dari faktor loadingnya faktor suasana tempat tinggal paling menentukan keberhasilan mahasiswa dalam belajar sehingga mempengaruhi perolehan prestasi belajar mahasiswa FE UNP dengan faktor loading sebesar 0.845, diikuti oleh faktor hubungan dengan keluarga sebesar 0,801 dan perhatian orang tua sebesar 0.701 . Faktor ini dapat menjelaskan keragaman varian sebesar $6.507 \%$.

Hasil penelitian ini sesuai dengan pernyataan Putriaji Hendikawati (2013-34) bahwa lingkungan keluarga ini terbentuk dari lingkungan tempat tinggal dan kondisi lingkungan keluarga. Dalam belajar mahasiswa membutuhkan suasana tempat tinggal yang sejuk dan nyaman. Disisi lain perhatian dan hubungan yang baik dari lingkungan keluarga akan menentukan sikap dan prilaku anak kedepannya.

Faktor 4 diberi nama etos belajar dengan nilai eigen values sebesar 1,732. indikator yang terdapat pada faktor ini yaitu kemauan dalam belajar, kesungguhan diri dan senang dalam memecahkan masalah belajar Faktor ini dapat menjelaskan keragaman varian sebesar $6,185 \%$. Apabila dilihat dari faktor loadingnya faktor kemauan belajar yang paling menentukan keberhasilan mahasiswa dalam memperoleh prestasi belajar yang baik dengan faktor loading 0.800 disusul oleh faktor kesungguhan diri untu belajar dengan faktor loading 0.613 dan terakhir faktor memecahkan masalah belajar dengan faktor loading sebesar 0.524. Menurut Sukarman yang dikutip oleh Supradnyani (2013-3) faktor kemauan belajar, kesungguhan diri dan keinginan menyelesaikan masalah belajar termasuk dalam kelompok faktor etos kerja.

Faktor 5 diberi nama konsentrasi belajar dengan nilai eigen values sebesar 1.609. Indikator yang terdapat pada faktor ini yaitu kondisi fisik, kelelahan dan perhatian dalam belajar dimana faktor ini dapat menjelaskan keragaman varian sebesar 5,745 $\%$. Apabila dilihat dari faktor loadingnya faktor kondisi fisik paling keberhasilan mahasiswa dalam memperoleh prestasi belajar yang baik dengan faktor loading 0.778, dan disusul oleh faktor kelelahan dengan faktor loading 0.681 , selanjutnya adalah faktor perhatian belajar dengan faktor loading sebesar 0,611.

Menurut Nugroho (2007) faktor kondisi fisik, kelelahan dan perhatian belajar termasuk dalam kelompok faktor konsentrasi belajar. Konsentasi belajar seseorang akan terganggu apabila tidak memiliki motivasi dalam diri artinya kurangnya perhatian untuk belajar. Selain itu kondisi kesehatan mahasiswa berupa kondisi fisik yang lemah atau sakit akan menghambat tercapainya hasil belajar yang maksimal.

Faktor 6 diberi nama pola makan dan keinginan berhasil dengan nilai eigen values sebesar 1.331. Indikator yang terdapat pada faktor ini yaitu pola makan dan keinginan untuk berhasil dimana faktor ini dapat menjelaskan keragaman varian sebesar 4,755\%. Apabila dilihat dari faktor loadingnya faktor pola makan paling menentukan keberhasilan mahasiswa dalam belajar dengan faktor loading 0.800 dan faktor keinginan diri untuk berhasil dalam belajar sebesar 0,597.

Faktor 7 diberi nama penunjang dengan nilai eigen values sebesar 1.159. indikator yang terdapat pada faktor ini yaitu kondisi belajar, ekonomi keluarga dan aktif dalam belajar. Faktor ini dapat menjelaskan keragaman varian sebesar $4,141 \%$. Faktor lokasi memiliki faktor loading sebesar 0.800 . Apabila dilihat dari faktor loadingnya, faktor kondisi belajar paling mempenagruhi mahasiswa dalam memperoleh prestasi belajar dengan nilai loading 0.678, dan disusul oleh faktor kelelahan dengan faktor loading 0.612 , selanjutnya adalah faktor aktif dalam belajar dengan faktor loading sebesar 0,576 .

Faktor ke 8 diberi nama pola asuh dengan nilai eigen values sebesar 1.159. Inidkator yang terdapat pada faktor ini hanya satu faktor yaitu cara orang tua mendidika anaknya. Faktor ini dapat menjelaskan 
keragaman varian sebesar 4,141\%. faktor lokasi memiliki faktor loading sebesar 0.800 . Pada dasarnya pola asuh dapat diartikan seluruh cara perlakuan orang tua yang diterapkan pada anak. Banyak ahli mengatakan pengasuhan anak adalah bagian penting dan mendasar, menyiapkan anak untuk menjadi masyarakat yang baik. Terlihat bahwa pengasuhan anak menunjuk kepada pendidikan umum yang diterapkan. Pengasuhan terhadap anak berupa suatu proses interaksi antara orang tua dengan anak. Interaksi tersebut mencakup perawatan seperti dari mencukupi kebutuhan makan, mendorong keberhasilan dan melindungi, maupun mensosialisasi yaitu mengajarkan tingkah laku umum yang diterima oleh masyarakat.

Berdasarkan hasil analisis faktor, terdapat 8 faktor yang mempengaruhi prestasi belajar mahasiswa FE UNP yaitu kualitas pengajaran, kemandirian belajar, lingkungan keluarga, etos belajar, konsentrasi belajar, penunjang, pola makan dan keinginan berhasil dan pola asuh. Analisis dilanjutkan dengan analisis regresi berganda untuk mengungkapkan dan melihat secara riil bagaimana pengaruh faktor baru yang ditemukan terhadap prestasi belajar mahasiswa FE UNP. Hasil dari uji lanjutan regersi berganda dapat dilihat sebagai berikut:

Tabel 6: Rekapitulasi Analisis Regresi Berganda

\begin{tabular}{cccc}
\hline Variabel Terikat & Variabel Bebas & t-Hitung & Sig. \\
\hline & X1 & 4.158 & .000 \\
X2 & 3.558 & .000 \\
X3 & 3.735 & .000 \\
Prestasi Belajar & X & 2.106 & .036 \\
X5 & X6 & 4.091 & .247 \\
X7 & X8 & 1.161 & .049 \\
\hline
\end{tabular}

\section{Sumber: Hasil Olahan Data SPSS 2014}

Faktor yang berpengaruh sangat signifikan dalam penelitian ini adalah kualitas pengajaran (X1), kemandirian belajar (X2), kondisi ekternal (X3) dan konsentrasi belajar (X5) karena memiliki nilai sig 0,00. Sedangkan pengaruh yang signifikan terdapat pada etos belajar (X4) dan variabel penunjang (X7) karena memiliki nilai sig 0,036 dan 0,049 . Untuk pola makan dan keinginan berhasil (X6) dan pola asuh (X8) dalam penelitian ini tidak berpengaruh signifikan karena memiliki nilai sig > 0,05. Jadi dapat disimpulkan bahwa dari delapan faktor baru dari analisis faktor dan dilanjutkan dengan analisis regresi berganda ternyata hanya enam faktor di atas yang berpengaruh terhadap prestasi belajar mahasiswa FE UNP.

Penyebab tidak berpengaruhnya pola makan dalam penelitian ini dikarenakan pola makan mahasiswa FE UNP secara keseluruhan tidak mendukung mereka dalam mencapai prestasi belajar yang baik artinya variasi penerapan pola makan yang sehat atau tidak pun tidak mendukung mahasiswa dalam meningkatkan prestasi belajarnya. Selain itu kondisi kesehatan dan konsentrasi dalam belajar akibat telat makan tidak mengganggu mahasiswa dalam melaksanakan aktivitas perkuliahan. 
Sejalan dengan itu keinginan untuk berhasil mahasiswa juga tidak berpengaruh dalam meningkatkan prestasi belajarnya. Hal ini terjadi karena keinginan berhasil dari mahasiswa berbeda-beda dan bervariasi, karena yang diinginkan adalah lulus dengan cepat tanpa ada prestasi yang dimiliki. Selanjutnya variabel pola asuh dalam penelitian ini tidak berpengaruh terhadap prestasi belajar mahasiswa. Pola asuh dalam penelitian ini dilihat dari indikator cara orang tua dalam mendidik anaknya. Didikan orang tua tidak lagi dirasakan oleh mahasiswa, karena secara keseluruhan mahasiswa tinggal jauh dari orang tuanya dan dalam menjalankan kehidupannya mahasiswa cendrung ingin menentukan pilihannya sendiri secara mandiri.

\section{KESIMPULAN}

Berdasarkan hasil penelitian dan pengolahan data yang dilakukan pada bab sebelumnya maka dapat ditarik kesimpulan sebagai berikut:

1. Terbentuk delapan faktor yang mempengaruhi prestasi belajar mahasiswa FE UNP diantaranya (a) Kualitas Pengajaran, indiaktor yang terdapat pada fakto ini yaitu kreativitas dosen, pemahaman dosen, ketersediaan sarana dan prasarana, referensi belajar dan suasana belajar di kampus, (b) Kemandirian Belajar, indiaktor yang terdapat pada faktor ini yaitu hasrat bersaing, mengambil inisitif, kerjasama dan persiapan belajar (c) variabel Lingkungan Keluarga, faktor-faktor yang terdapat pada variabel ini yaitu suasana tempat tinggal, hubungan keluarga dan perhatian orang tua, (d) Etos Kerja, indiaktor yang terdapat pada faktor ini yaitu kemauan belajar, kesungguhan diri dan kemampuan menyelesaikan masalah, (e) Konsentrasi Belajar, indiaktor yang terdapat pada faktor ini yaitu kondisi fisik, kelelahan dan perhatian belajar (f) Pola Makan dan Keinginan Berhasil, indiaktor yang terdapat pada faktor ini yaitu pola makan dan keinginan berhasi, (g) Penunjang Belajar, indiaktor yang terdapat pada faktor ini yaitu kondisi belajar, ekonomi keluarga dan aktif dalam belajar (h) Pola Asuh faktor indikator yang ada dalam faktor ini cuma satu yaitu cara didikan orang tua

2. Dari delapan faktor yang mempengaruhi prestasi belajar mahasiswa Fakultas Ekonomi Universitas Negeri Padang, faktor dominan yang mempunyai pengaruh besar adalah faktor kualitas pengajaran. Faktor-faktor yang terbentuk memberikan sumbangan persentase kumulatif variance sebesar 69,29\%, sedangkan sisanya sebesar $30,71 \%$ dijelaskan oleh indikator lain yang tidak termasuk dalam indikator yang peneliti teliti.

3. Hasil analisis regresi berganda menunjukan bahwa dari delapan variabel baru yang terbentuk, hanya 6 variabel yang berpengaruh signifikan terhadap prestasi belajar mahasiswa yaitu kualitas pengajaran (X1), kemandirian belajar (X2), Lingkungan Keluarga (X3), etos kerja (X4), konsentrasi belajar (X5) dan penunjang dengan perolehan sig $<0,05$. Sedangkan faktor pola makan dan keinginan berhasil (X6) dan pola asuh (X8) dalam penelitian ini tidak berpengaruh karena memiliki nilai sig > 0,05

Bertitik tolak dari hasil penemuan empiris sebelumnya dan hasil penemuan empiris dari studi ini, maka penulis mengemukakan saransaran sebagai berikut :

Berdasarkan kesimpulan diatas, maka penulis memberikan saran untuk meningkatkan prestasi belajar mahasiswa Fakultas Ekonomi Universitas Negeri Padang sebagai berikut:

1. Bagi dosen dalam melaksanakan proses pengajaran diharapkan terus menggali pemahamannya terhadap materi pelajaran agar mudah disampaikan kepada mahasiswa dan mahasiswa mampu menangkap apa yang diberikan oleh dosen.

2. Diharapkan kepada mahasiswa untuk meningkatkan kemandirian belajar dengan cara mempunyai inisitif untuk 
belajar, membangun hubungan positif dengan teman sebaya dalam membantu meningkatkan prestasi belajar. Etos belajar juga harus dilaksanakan oleh mahasiswa dengan cara bersungguhsungguh dan memiliki kemauan yang kuat untuk sukses dalam belajar. Hal lain yang juga harus menjadi perhatian bagi mahasiswa yaitu tingkatan konsentrasi belajar mahasiswa dengan cara memperhatikan kesehatan mahasiswa kesehatan fisik dan non fisik dan olahraga secara teratur agar kondisi badan tetap fit untuk belajar

3. Diharapkan kepada orang tua untuk membimbing dan memperhatikan anak baik di kampus maupun di rumah. Perhatian yang diberikan orang tua melalui komunikasi yang baik, hubungan yang akur dengan anggota keluarga sehingga menciptakan suasana tempat tinggal yang kondusif untuk belajar sehingga kemungkinan untuk memiliki prestasi belajar rendah bisa diperkecil.

\section{DAFTAR PUSTAKA}

10.22202/economica.2015.v4.i1.325

Ahmadi, Abu. 2010. Psikologi Belajar. Jakarta: PT Rineka Cipta.

Cumhur Erdem dkk . 2007. Factors Affecting Grade Point Average of University Students. The Empirical Economic Letter. ISSN (360-366).

Farida dkk. 2013. Faktor-Faktor yang Mempengaruhi Prestasi Belajar Akuntansi Siswa Kelas IX IPS SMAN Ponorogo.Jupe UNS. Vol 1 No 3. Hlm (106-117)

Hendika, Putriaji. 2010. Analisis Faktor yang Mempengaruhi IPK Mahasiswa. Jurnal Inspirasi Pendidikan Universitas Kenjuruhan Malang. Vol 1 No 1. Hlm. 27-35.

H.A.R Tilaar, Beberapa Agenda Reformasi Pendidikan Nasional dalam Perspektif
Abad 21, Tera Indonesia: 1998, Magelang. Hal.249

Karyanus, dkk. 2013. Analisis Statistik Faktor-Faktor yang Mempengaruhi IPK Mahasiswa. Saintia Matemtika. Vol 1, No 5. Hlm 483-494

Purwanto, Ngalim. 2011. Ilmu Pendidikan Teoritis dan Praktis, Bandung: PT Remajakarya

Riduwan. 2006. Belajar Mudah Untuk Penelitian Baru, Karyawan, Penelitian Pemula. Alfabeta: Bandung.

Sardiman, A.M. 2012. Interaksi dan Motivasi Belajar Mengajar: Jakarta: PT. Raja Grafindo Persada.

Suharmini, Arikunto. 2010. Prosedur Penelitian. Jakarta: Rineka Cipta.

Suryabrata, Sumadi. 2009. Psikologi Pendidikan. Jakarta : PT. Raja Grafindo Persada.

Sumadji dkk. 2011. Motivasi dan Cara Belajar Mahasiswa Program Studi Pendidikan Matematika. Jurnal Inspirasi Pendidikan Universitas Kenjuruan Malang.Vol 1 No 1. Hlm. 56-66.

Supranto, J. 2010. Analisis dan Interpretasi Multivariat. Jakarta : PT. Raja Grafindo Persada.

Sofyan, Rita. 2014. Analisis Faktor-faktor yangv Menentukan Minat menjadi Guru pada program studi kependidikan UNP, Tesis, Magister Pendidikan Ekonomi. Universitas Negeri Padang.

Titik Haryati dan Noor Rochman, 2012. Peningkatan Kualitias Pembelajaran Pendidikan Kewarganegaraan Melalui Praktik Belajar Kewarganegaraan (Project Citizen). Jurnal Ilmiah CIVIS. Vol II. No. 2. 